\title{
Investigation of transportation investments in Bursa in terms of urban-environment- community relations
}

\section{Bursa'daki ulaştırma yatırımlarının kent-çevre-toplum ilişkileri açısından incelenmesi}

\author{
Ahmet Ünal 1,*(iD, Ahmet Tortum² \\ ${ }^{1}$ Erzurum Technical University, Engineering and Architecture Faculty, Civil Engineering Department, 25050, Erzurum, Turkey \\ ${ }^{2}$ Atatürk University, Engineering Faculty, Civil Engineering Department, 25240, Erzurum, Turkey
}

\begin{abstract}
Distribution of public investments by sectors is an important indicator in understanding the economic conditions of countries. While developing countries make intensive spending in the transportation, health and construction sectors; developed countries, on the other hand, work in the fields of open industry, software, space and aviation. In Turkey, which is among the developing countries in areas such as defense and military industry mega investments made significant investments in transportation is done. In the case of Bursa is Turkey's 4th largest city is also one of the most important cities in the automotive sector. Due to this location of Bursa, it has been one of the provinces affected by mega projects (Osman Gazi Bridge, Istanbul-Bursa-İzmir highway, etc.) made in the field of transportation in recent years. Apart from these projects, significant transportation investments have been made in Bursa in the city center in recent years. Within the scope of this study, transportation investments made in Bursa province in recent years have been examined. The urban-environment-community relationship has been investigated by investigating the positive and negative sides of these projects.
\end{abstract}

Keywords: Bursa, Transportation investments, Transportation sector, Mega projects

\section{Introduction}

One of the most important parameters in the development indicators of countries is the distribution of rates in public investments by sectors. While investments in technology, space and aviation fields in developed countries have an important share; investments in construction, transportation and health sectors are given priority in developing and undeveloped countries. Investments in technology in the third quarter of 2019 was around 55 billion dollars in the United States and in Europe \$ 9 billion in Turkey stood at 36 million dollars [1]. On the other hand, when we examine the construction and transportation investments of the countries, when the budgets allocated to these areas are proportioned according to the annual income, the ranking of the countries shows the opposite direction. In short, while the
Özet

Kamu yatırımlarının sektörlere göre dağılımı, ülkelerin ekonomik durumlarının anlaşılmasında önemli bir göstergedir. Gelişmekte olan ülkeler ulaşım, sağlık ve inşaat sektörlerinde yoğun harcamalar yaparken; gelişmiş ülkeler ise sanayi, yazılım, uzay ve havacılık alanlarında çalışmaktadır. Gelişmekte olan ülkeler arasında yer alan Türkiye'de savunma ve askeri sanayi gibi alanlarda mega yatırımlar yapılıyorken ulaştırma alanında da önemli yatırımlar yapılmaktadır. Bursa Türkiye'nin 4. büyük şehri olmasının yanında otomotiv sektörünün de en önemli şehirlerinden biridir. Bursa'nın bu konumundan dolayı son yıllarda ulaşım alanında yapılan mega projelerden (Osman Gazi Köprüsü, İstanbul-Bursa-İzmir karayolu vb.) etkilenen illerden biri olmuştur. Bu projelerin dişında Bursa'da son yıllarda şehir merkezinde de önemli ulaşım yatırımları yapılmıștır. Bu çalıșma kapsamında Bursa ilinde son yıllarda yapılan ulaşım yatırımları incelenmiştir. $\mathrm{Bu}$ projelerin olumlu ve olumsuz yanları incelenerek kent-çevre-toplum ilişkisi araştırılmıştır.

Anahtar kelimeler: Bursa, Ulaştırma yatırımları, Ulaştırma sektörü, Mega projeler

appropriations allocated to fields such as technology, space and aviation in developed countries have a large share in annual budgets; in developing countries, the appropriations allocated for construction, health, and transportation have a larger share within the annual budget. Turkey is OECD and the G-20 countries, although there is not yet completed the development literally but transport in recent years, health care, besides it has accelerated its efforts in the area of infrastructure work in the defense and arms industry, as do other developed countries are located in important activities.

When we examine the transportation investments in Turkey appears to be especially great strides in the last 20 years. Some of the investments such as Marmaray, Yavuz Sultan Selim Bridge, Istanbul New Airport, 1915 Çanakkale Bridge, Osman Gazi Bridge, which are mentioned as

\footnotetext{
* Corresponding author, e-mail: ahmet.unal@erzurum.edu.tr (A. Ünal)

Geliș / Recieved: 30.12.2020 Kabul / Accepted: 09.09.2021 Yayımlanma/ Published: 14.01.2022

doi: $10.28948 /$ ngmuh. 850147
} 
national scale mega investments, have been completed and some of them have come to the stage of completion. Apart from these major investments in the country experienced a great leap forward in the last 20 years, divided highway construction and the total length of divided highways in Turkey as of 01.01.2020 was $25705 \mathrm{~km}$ [2]. In addition to these transportation investments in the national scale, many studies related to urban public transportation and transportation activities were carried out locally. These; as well as works such as tram and metro, studies on maritime public transportation have been carried out, especially through organizations such as Bursa Sea Bus Operations (BUDO) and Istanbul Sea Bus Operations (IDO) in Bursa and Istanbul.

This study examines the transportation investments made in the case of Turkey's $4^{\text {th }}$ largest city of Bursa and this work is evaluated in terms of urban-environment-society relations. In addition to the completed studies, it was tried to express the positive and negative aspects of the future planned studies by evaluating them. With this study, it is aimed to contribute to the correction of errors in the transportation investments currently made in Bursa province. In addition, the study aims to act as a bridge between the transportation investments made in the past, ongoing and planned in the future. Thus, this article will serve as a projection for future investments.

\section{Literature review}

Managers are required to distribute investments between regions and cities in a balanced way. In order to reveal this relationship and to provide a detailed projection of the investments made, studies are carried out especially by the relevant ministries and scientists.

Kalaycığlu [3] examined transport relations in different geographical levels for regional transportation planning in Turkey. In the study, he stated that there is a need to develop a transportation system formed by relations and priorities at different geographical levels in order to plan regional transportation investments outside the urban transportation infrastructure.

Bilgiç [4] emphasized the importance of the decisionmaking process in the evaluation of transport investment in Turkey. He stated in his study that the organizational structure of an investment system for transportation investments and the decision-making process should be based on scientific principles and should not contradict the principles of transparency.

Karaman and Altan [5] evaluated transportation investments financially. In their studies, they analyzed the indicators about the economic conditions of countries such as transportation investments, welfare level and transportation investments in developed economies.

Bilgicler [6] multi-criteria for the evaluation of transport investment in Turkey has been associated with the development of a method. In his study, he determined one of the multi-criteria evaluation methods as the cost of money cost. The study also proposed 18 criteria for other effects ranging from time values to compliance with transport plans. Durmus [7] transportation investment and economic growth relationship has worked on Turkey's economy.

Oytun [8] examined the impact of transportation networks on economic integrations and the Turkish world dimension. He studied the effects of transport infrastructures and networks on welfare levels. In addition, the relationship between welfare systems and economic integrations has been examined.

Sobieralski [9] stated between 1990 and 2018, he studied the effects of transportation investments on employment in the field of statistics in 11 metropolitan cities in the USA. In his study, he concluded that highway infrastructure investments have the greatest positive effect on employment in general. However, he stated that attention should be paid to other social externalities related to transportation.

Jiang et al. [10] discussed the two-way relationship between multimodal transport investment and economic development.

Rizelioğlu [11] carried out the study of modeling the Bursa light rail system line as a metrobus. In his study, the status of the existing Light Rail System (HRS) in Bursa was analyzed with PTV VISSIM, which is one of the important traffic simulation programs. Then, a comparison was made with other public transportation (Metrobus) that could be substituted, taking into account some performance criteria such as capacity and comfort.

Şimit et al. [12] analyzed Turkey's first domestic tram silkworm. In the study, the silkworm line was evaluated with the SWOT (Strengths, Weaknesses, Opportunities, Threats) analysis method.

Rizelioğlu and Arslan [13] assessed the existing Bursa light rail transportation system.

\section{Study area}

Bursa has always been one of the important cities of the states to which it is connected in the historical process. The fact that Bursa is on the route of the road named as Silk Road has been a factor in the fact that it is one of the important cities in the industry especially in the textile sector (Figure 1) [14]. During the foundation period of the Ottoman Empire, Bursa became the capital and due to this feature, there are many historical buildings in the city, which is especially effective for tourists to come to the city at the point of cultural tourism. In the Republican period, many textile factories were established and made a significant contribution to the national economy in terms of employment and economic activities.

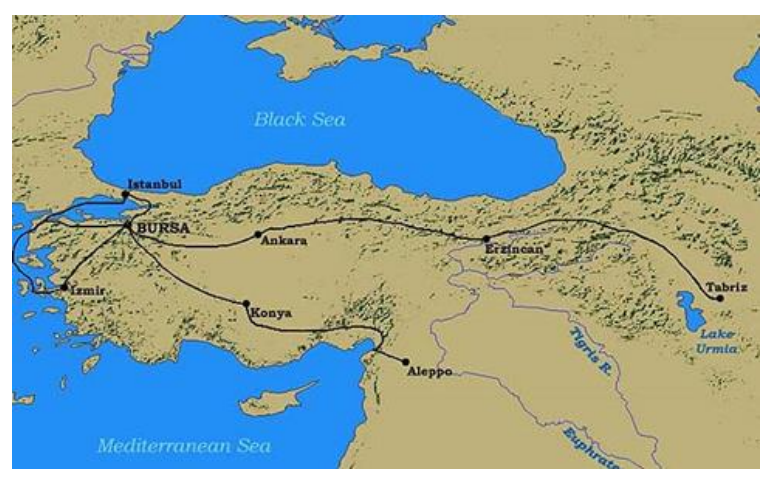

Figure 1. The location of Bursa [14] 
When we evaluate the location of Bursa in the country, it is located in the middle of the Istanbul-Izmir highway and forms one leg of the Istanbul-Bursa-Izmir highway connecting these two important cities. In addition, it is one of the compulsory waypoints to go to our cities, such as Antalya and Mugla, which are among the important tourism cities of the country. With all these aspects, Bursa city has an important place in the country's economy, investments and employment resources.

\section{Transportation investments in Bursa province}

Especially, the investments made on transportation activities in Bursa, whose population has increased rapidly as a result of human migration from other cities in the last 20 years, draw attention. Along with the projects on a national scale, which concern other cities, investments made especially in public transportation in the city attract attention. The costs of the projects directly and indirectly related to the province of Bursa are shown in Table 1.

Table 1. Project costs

\begin{tabular}{ccc}
\hline The Project Name & Cost & Construction Year \\
\hline Osmangazi Bridge & 1.2 billion Dollars & 2015 \\
Istanbul-Bursa-Izmir & [15] billion Dollars [16] & 2019 \\
Highways & 8,5 million Euro [17] & 2013 \\
T-1 Tram Line & 30 million Dollars & continues \\
T-2 Tram Line & [18] & 2011 \\
T-3 Tram Line & 3,5 million Euro [17] & continues \\
High Speed Train & 3 billion TL [19] & \\
\hline
\end{tabular}

Undoubtedly, capacity is an important factor in the choice of public transportation vehicles. When the capacity of public transportation types is examined, it is seen that rail system transportation is more advantageous than other public transportation types in terms of capacity (Table 2).

Table 2. Public transport types capacity values [20]

\begin{tabular}{cc}
\hline Passenger Transport System & $\begin{array}{c}\text { Passenger Capacity } \\
\text { (passenger/hour/direction) }\end{array}$ \\
\hline Commuter Train & $40.000-60.000$ \\
Light Rail System & $15.000-22.000$ \\
Articulated Bus (on private roads) & $12.000-20.000$ \\
Articulated Bus & $10.000-15.000$ \\
Bus & $8.000-12.000$ \\
Minibus & $6.000-10.000$ \\
Automobile & $2.000-5.000$ \\
\hline
\end{tabular}

Below, the most important of the transportation investments made in Bursa in recent years are examined; positive and negative aspects of these investments within the framework of the urban-environment-community relationship are explained.

\subsection{Light rail system}

The construction of the light rail system started on 08.07.1998 and the first passenger was transported on 23.04.2002 [21]. This line consists of 2 different routes, two routes starting from the Small Industry and Organized Industrial Zones joined at the Acemler and then ended at the Şehreküstü station [22]. Over time, the first and third stages followed. After this stage, the rail system line was extended from Şehreküstü to Arabayatag1, and then the eastern stage was completed by extending from Arabayatag1 to Kestel. On the west side of the Light Rail System, the line from Küçük Sanayi to the University has been extended and the line from Organize Sanayi station to Emek has been extended (Figure 2) $[23]$.

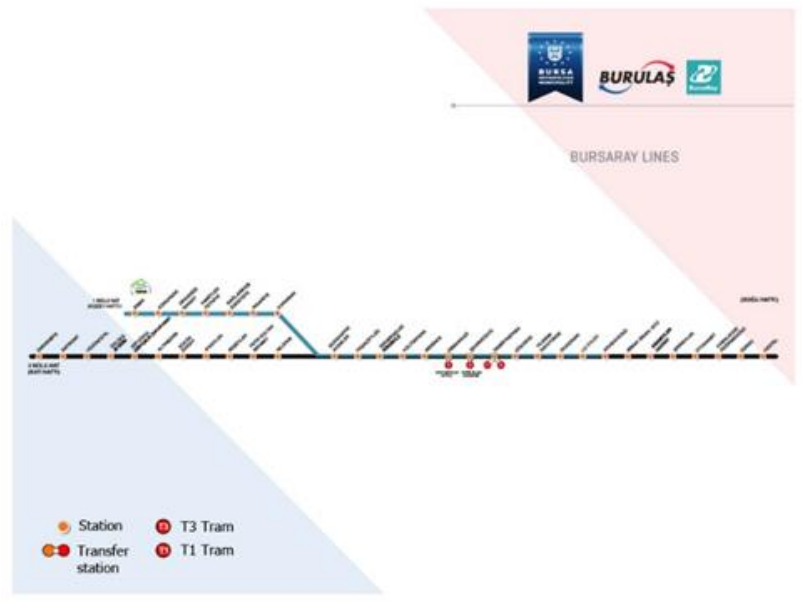

Figure 2. Light rail system line [23]

Finally, the efforts to extend the Light Rail System to Bursa City Hospital have started today. In addition, with the arrival of the Highspeed Train Line, which is expected to be completed soon, the rail system line is also expected to be extended to Balat.

\subsection{T-1 (Silkworm) tram line}

The Silkworm Tram line is an investment to meet the passenger demand in the city center. This line is defined as the T1 tram line and makes ring trips between Kent Square and Sculpture. This line mostly proceeds in the same place as road traffic and there is no special part reserved for it. The length of the line is 6.5 kilometers and there are total of 15 stops (Figure 3) [23,24]. In fact, the carrying capacity of the operating tram is about 320 people, including 48 seated passengers [25]. This line was put into operation at the beginning of 2014 and still provides services.

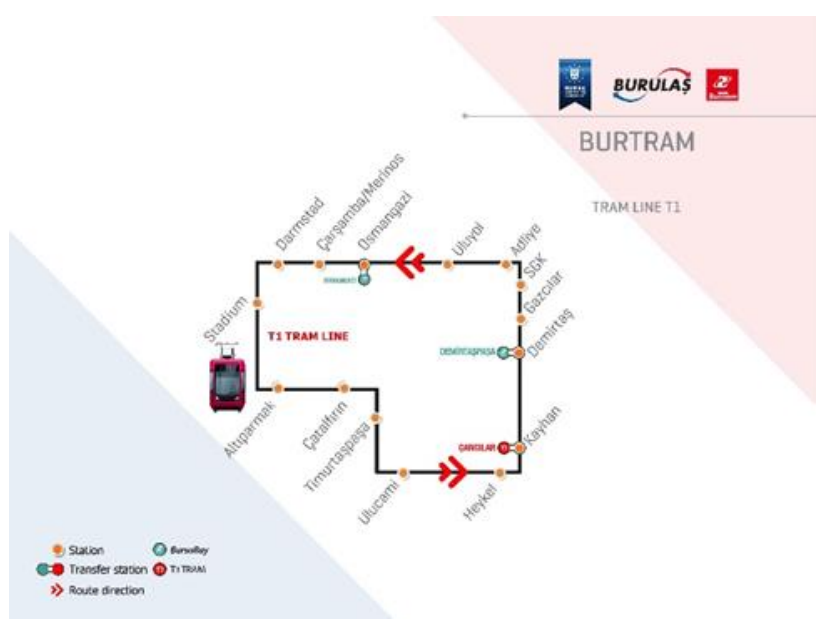

Figure 3. Silkworm tram line [24] 
In addition, the tram used for transportation on the line is $100 \%$ local and is also produced in Bursa. The construction cost of this line is approximately $€ 8.5$ million, excluding vehicles on it [17].

\subsection{T-2 tram line}

The $\mathrm{T}-2$ tram line is perhaps one of the most controversial transportation investments for Bursa, which is still under construction today. This line will be operated between City Square and Bus Terminal, it is 8.3 kilometers long and will consist of 11 stations [26]. The fact that Bursa will connect two dense regions together shows the necessity of the line; Whether this line should be a light rail system or not will be revealed in the coming years. The fact that the line is not built underground and is at the same level with the highway will cause inadequacy of the existing highway. In addition, if we consider that the passengers coming to the intercity bus station will transfer from Kent Square station using T1 or Light Rail System, they will have to walk about 200 meters from Kent Square, the last stop of the T2 line, to other transfer stops (Figure 4) [27].

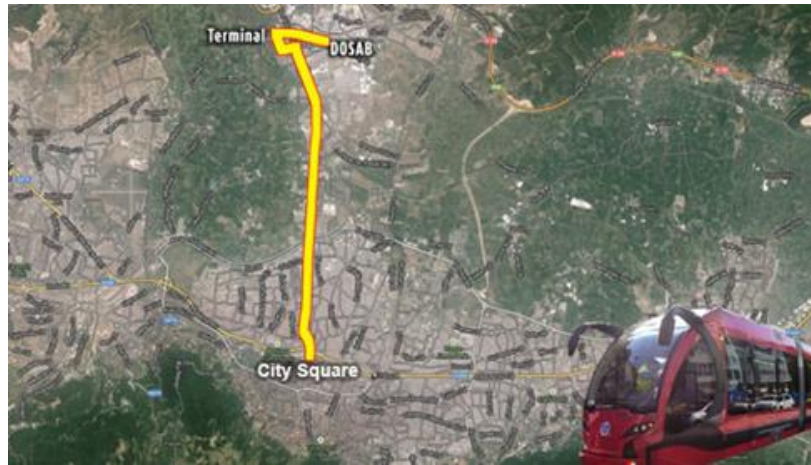

Figure 4. T-2 Tram line [23]

\section{$4.4 \quad$ Nostalgic tram line}

The nostalgic tram line starts from Çınarönü and ends at Zafer Plaza stop and is approximately 2.2 kilometers long. It even has 9 stops in total and has a capacity of about 60 passengers [28]. With this line built and passenger transportation started, almost a 100-year dream has come true and transportation has started to the Hanlar Region, the city's busy commercial area (Figure 5) [23].

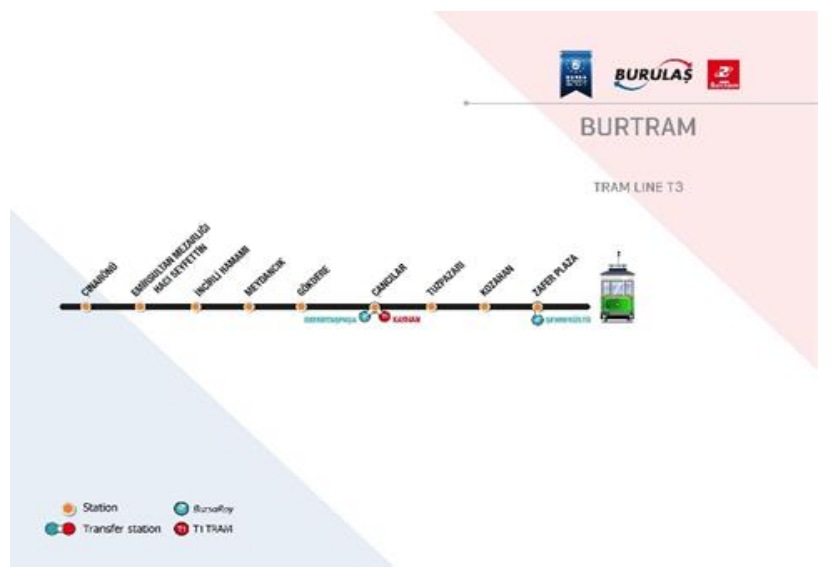

Figure 5. T-3 Tram line [23]
With the construction and completion of this line, Cumhuriyet Street, one of the most important streets of the city, was closed to vehicle traffic, only for pedestrians and nostalgic trams. The cost of this project is 3.5 million Euros, excluding vehicles to be used for transportation on the line, and the estimated number of passengers carried is around 7000 per day $[17,29]$.

\subsection{High speed train line}

With the acceleration of rail transportation in our country in the last 20 years, high-speed railway lines have been started to be built. The high-speed railway line, which was first completed between Ankara and Eskişehir, continued with the completion of the Konya-Ankara and EskişehirIstanbul lines. The construction of the Eskişehir-Bursa line is still ongoing. about $70 \%$ of them are at the finishing stage (Figure 6) [30, 31].

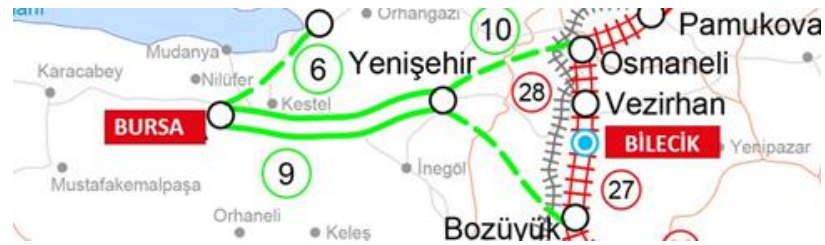

Figure 6. High speed train line [30]

\subsection{Istanbul-Bursa-Izmir highway}

In the event of Turkey's most important city project linking the Istanbul-Bursa-Izmir highway construction with the completion of these cities work together even closer and long-distance travel have been easier. Undoubtedly, the important cultural, tourism and trade centers of the country are located in these provinces, and the importance of this project has increased even more. The total length of this highway is 384 kilometers, the highway is 426 kilometers along with connection roads, and the time between Istanbul and Izmir, which lasted 9 hours, reduced to 3.5 hours (Figure 7) [32].

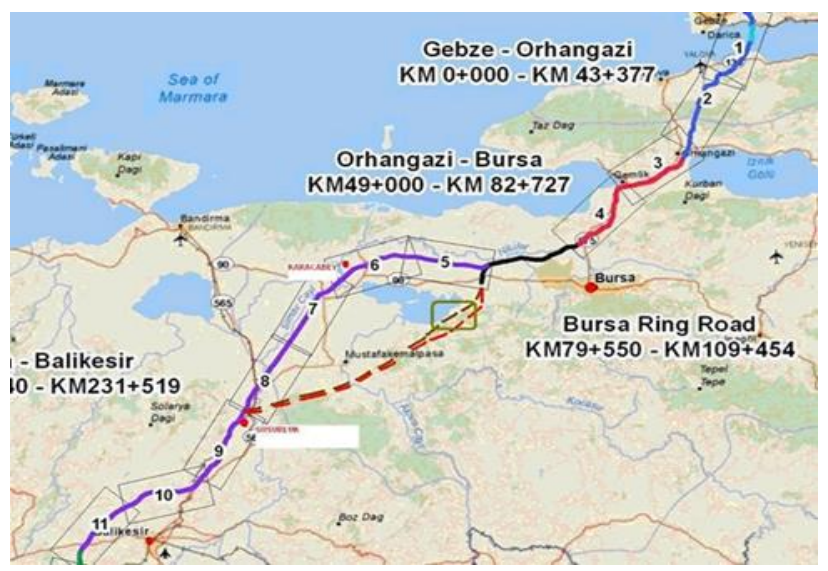

Figure 7. Istanbul-Bursa-Izmir highways [32]

\section{Conclusions}

Significant investments have been made in the transportation sector in Bursa, especially in the last 20 years. This investment further enhances the importance of Bursa, which is already an important city for Turkey. There is no 
doubt that these transportation investments, like all projects, have shortcomings. Especially in Bursa, where the country's important agricultural product needs are met together with its fertile plain, the implementation of projects over the agricultural areas without considering these agricultural activities negatively affects the agricultural activities of the farmers.

Errors in feasibility studies before projects are implemented lead to misuse of the public budget. For example, when a tram project is applied to a place where a light rail system is required, both time and money are lost for a project that will be insufficient in the future. In order to prevent such wrong practices, feasibility studies should be done comprehensively and priority should be given to projects that will save the future rather than the policies that save the day. Otherwise, the investments made will not be effective on the expected problems and will also waste money.

\section{Results and discussions}

Population growth in metropolitan cities especially in recent years causes many problems in cities. Problems such as transportation, traffic density, healthcare concentrations, and infrastructure problems can be cited as the main problems. Managers are working to solve these problems. There are projects that they have been successful in solving these problems, as well as projects where they have not found a permanent solution to the problems. In order for the budget allocated to public investments to be used efficiently, it is necessary to work in coordination with the experts and non-governmental organizations. Otherwise, the projects will cease to be solution-oriented and further increase confusion. In this study, suggestions were made whether the transportation investments made in Bursa in the last 20 years were effective in solving the problems, and the projects that were effective and not used effectively would increase the efficiency.

The Bursaray Light Rail System project was sufficient to meet the demand for public transportation in the first years of its use. However, over the years, the demand for travel has increased with the expansion of the Bursaray line and the integration of other transportation systems to Bursaray. As a result, passenger density is experienced, especially at certain times of the day. When we examine the harmony of Bursaray with the city, it causes narrowing of the highway and increases the traffic density especially in the regions where the city has a dense population.

When we examine the T-1 tram line, the expected efficiency from the tram transportation system in terms of passenger transportation cannot be obtained. In order for the tram system to be feasible, it must be 15.000 passengers / day. As of 2018, the daily usage amount on the T-1 tram line was 8.500 passengers / day. This shows that the $\mathrm{T}-1$ line is far below its purpose. The emergence of this result is that there are many different types of public transportation in the same direction as the route of the T-1 tram line. In order to use this line efficiently, especially buses moving on the route where the T-1 line passes must be integrated and operated.

The T-2 tram line was perhaps one of the most discussed projects among the existing projects. Discussions continued both in the selection of the type of public transportation and in the location of the stations. At first, metrobus transportation was considered instead of tram transportation. Later, it was decided on tram transportation, but unlike traditional tram projects, this project is planned to leave the highway and enter it on its own line. Considering the minimum required number of passengers in tram transportation and the number of passengers carried by buses on the current route this project has passed, it may be considered that this project will not be feasible at first. However, with this current increase of Bursa, which has a population of increasing population, it is clear that the presence of Demirtaş Organized Industrial Zone and other industrial facilities on the line will increase the travel demand of the region in the future. For this, at least the project that was made had to be designed in such a way that it would be integrated into the light rail system in case the demand for passengers increased.

The T-3 nostalgic tram line is currently on the agenda and the desired efficiency could not be obtained from the line. In fact, this line is advantageous in accessing the touristic areas of Bursa by its location. To activate this line, firstly integrating 1326 Panorama Bursa with the Conquest Museum; It is necessary to ensure that the tour buses carrying especially the tourist groups coming from outside the city park in this region. Thus, buses will not cause traffic problems by not entering the area where historical artifacts are located, and people coming to the city for touristic activities will have used the T-3 nostalgic tram line.

Construction work on the high-speed train line is currently ongoing, and work on electromechanical activities has not started yet. With the completion of this project, a new stage will be started in Bursa's transportation with Ankara and Eskişehir.

The opening of the Istanbul-Bursa-İzmir highway caused a decrease in the time spent on transportation of these cities. However, the fact that this road is not preferred by the majority of the society is due to the fact that the Osman Gazi Bridge passage fee, which provides great advantage in crossing the Gulf of Izmit, is high. Effective use of this project will be ensured by updating this bridge and highway prices.

\section{Conflict of interest}

The authors declare that there is no conflict of interest.

Similarity rate (iThenticate): $9 \%$

\section{References}

[1] KPMG,https://home.kpmg/tr/tr/home/medya/pressreleases/2020/02/teknoloji-girisimlerine-milyarlaryagiyor.html, Accessed 20 July 2020.

[2] KGM, Available from: https://www.kgm.gov.tr/ Sayfalar/KGM/SiteTr/Kurumsal/YolAgi.aspx, Accessed 20 July 2020.

[3] M. Kalaycioglu, Different geographical regional transportation planning in Turkey examining transportation relations at levels, 12. Transportation 
Congress, 135-146, Adana, Turkey, 24-26 May 2017.

[4] Ş. Bilgiç, Evaluation of transportation investment decision process in Turkey, 7. Transportation Congress, 17-26, Eskişehir, Turkey, 19-21 September 2007.

[5] E. Karaman, and M.F. Altan, Evaluation of transportation infrastructure investments in terms of finance, Journal of Istanbul Aydin University,77-87, 2017.

[6] Ş. Bilgiç and G. Evren, A suggestion for evaluation of transportation investments in Turkey, Itu Journal 1(2), 88-89, 2002.

[7] D. Özay, Transport investment relationship and growth: economic sample. Msc Thesis, Namik Kemal University, Tekirdağ, 2019.

[8] O. Meçik, The impact of transportation networks to the economic integrations, and Turkish world dimension. Uşak Universiy Journal of Social Sciences, 5(2), 22-33, 2012.

[9] J.B. Sobieralski, Transportation infrastructure and employment: Are all investments created equal?, Research in Transportation Economics, Article in Press, 2020.

[10] X. Jiang, X. He, L. Zhang, H. Qin, F. Shao, Multimodal transportation infrastructure investment and regional economic development: A structural equation modeling empirical analysis in China from 1986 to 2011, Transport Policy, 54, 43-53, 2017.

[11] M. Rizelioğlu, Modelling Bursa lrt system as bus rapid transit. Msc Thesis, Uludağ University, Bursa, 2015.

[12] K.O. Şimit, M. Rizelioğlu, T. Arslan, An analyzing on the Turkey's first local tram silkworm line. Uludağ Univeristy, Journal of Engineering Faculty, 21 (2), 489 498, 2016.

[13] M. Rizelioğlu and T. Arslan, Assessing the existing Bursa light rail transportation system. Transportation Research Record Journal of the Transportation Research Board,2674 (3), 1-11, 2020.

[14] Silk Road, http://depts.washington.edu/silkroad/ cities/turkey/bursa/bursa-map.jpg, Accessed 20 July 2020 .

[15] Osmangazi Bridge Highway Cost, https://www.ensonhaber.com/gundem/istanbul-izmirotoyoluaciliyor\#: :text=dolara\%20mal\%20oldu, \%C4 \%B0stanbul\%2D\%C4\%B0zmir\%20Otoyolu\%2C\%20 $11 \% 20$ milyar\%20dolara $\% 20$ mal $\% 20$ oldu, $\% \mathrm{C} 4 \% \mathrm{~B} 0 \mathrm{z}$ mir\%20Otoyolu\%20a\%C3\%A7\%C4\%B $11 \% \mathrm{C} 4 \% \mathrm{~B} 1 \%$ C5\%9F\%C4\%B1nda\%20vatanda\%C5\%9Flara\%20ses lendi., Accessed 20 July 2020.

[16] H. Kılıçaslan, Expanding the rail transport services of municipalities: the case of bursa metropolitan municipality, Journal Of Management And Economics,
22(2), 451-466, 2015.

[17] T-2, https://rayhaber.com/2018/12/aktastan-mujde-t2tramvay-hatti-bursaraya-entegre-olacak/, Accessed 20 July 2020.

[18] High Speed Train, https://www.olay.com.tr/ yazar/ahmet-emin-yilmaz/trenimiz-de-kume-dustuadi-artik-hizli-tren-degil-282818, Accessed 20 July 2020.

[19] Burulaş, https://www.burulas.com.tr/bursaray-genelbilgiler.aspx, Accessed 20 July 2020.

[20] M.A. Gençer and T. Eren. Ankara metro line movement hours be scheduled m1 (Kizılay-Batıkent). APJES 4 (2), 25-36, 2016.

[21] Bursaray,https://www.wikiwand.com/tr/Bursa_metros u_istasyonlar\%C4\%B1_listesi, Accessed 20 July 2020.

[22] Burulaş.https://www.burulas.com.tr/hatguzergahi.aspx ,Accessed 20 July 2020.

[23] Bursaray, https://rayhaber.com/2012/11/bursarayguzergahi-nereler-kac-istasyon-var/, Accessed 20 July 2020.

[24] İpekböceği.https://tr.railturkey.org/2015/04/30/durmar ay-ipekbocegi-tramvay/, Accessed 20 July 2020.

[25] T-2Tramvay. http://www.protamuhendislik.com.tr/ TR/haberler/bursa-kent-meydani-terminal-t2-tramvayhatti\#: :text=8.3\%20km\%20hat $\% 20$ uzunlu $\% \mathrm{C} 4 \% 9 \mathrm{Fu}$ \%20ve, $\%$ C3\%A7al\%C4\%B1\%C5\%9Fmalar\%C4\%B $1 \% 20$ Prota $\% 20 \mathrm{M} \% \mathrm{C} 3 \% \mathrm{BChendislik} \% 20$ taraf\%C4\% B1ndan\%20ger\%C3\%A7ekle\%C5\%9Ftirilmektedir., Accessed 20 July 2020.

[26] T-2Tramvay, https://www.trthaber.com/haber/ ekonomi/bursada-t2-tramvay-hattinda-imzalar-atildi212478.html, Accessed 20 July 2020.

[27] G. Baştürk, Review of urban rail mass transport systems and comparing with world samples, Transportation and Communication Expertise Thesis, Ankara, 2014.

[28] T-3 Tramvay,https://www.bursa.bel.tr/tramvay-gunde7-bin-yolcu-tasiyor/haber/11965, Accessed 20 July 2020.

[29] High Speed Train, https://tr.railturkey.org/2015/ 11/03/bandirma-bursa-osmaneli-hizli-tren-hatti/, Accessed 20 July 2020.

[30] YHT, https://www.bilecikhaber.com.tr/bursa-bilecikyht-projesinde-son-durum-333947h.htm, Accessed 20 July 2020.

[31] Bursa Highways, http://wowturkey.com/forum/ viewtopic.php?p=2810504, Accessed 20 July 2020.

[32] Istanbul-Izmir, https://www.sozcu.com.tr/2019/ ekonomi/istanbul-izmir-arasi-mesafe-azaliyor-otoyolerken-acilacak-5183679/, Accessed 20 July 2020. 